\title{
SUSTAINABLE BEHAVIOUR: \\ EVIDENCE FROM LITHUANIA
}

pages: $80-92$

\section{RAMUNĖ ČIARNIENĖ* (i) MILITA VIENAŽINDIENĖ \\ RŪTA ADAMONIENE்}

\begin{abstract}
A B S T R A C T
There is an increasing focus on bridging human behaviour and attitudes towards sustainability. This article focuses on the factors that influence sustainable behaviour of working people. Based on a systematic and comparative analysis of scientific literature, the authors of the paper present the theoretical conceptual model, which illustrates sustainable behaviour. The aim of the empirical research is to examine how employees relate to sustainable behaviour across generations, genders and different modes of education through economic, environmental and social domains. A quantitative method in the form of a survey was selected to capture individual employee attitudes and actions regarding sustainable behaviour. A total of 412 complete responses from Lithuanian employees were used for data analysis. The results of empirical research revealed a significant relationship between gender, generation and education, and sustainable employee behaviour.
\end{abstract}

KEY WORDS

sustainability, employee-related factors, sustainable behaviour

10.2478/emj-2020-0007
Ramunè Čiarniené

Kaunas University of Technology, Lithuania ORCID 0000-0001-6349-5352

*Corresponding author: e-mail: ramune.ciarniene@ktu.It

Milita Vienažindiené

Vytautas Magnus University, Lithuania ORCID 0000-0001-9894-6811

Rūta Adamonienè

Mykolas Romeris University, Lithuania ORCID 0000-0002-7716-8093

\section{INTRODUCTION}

Humanity is facing increasingly complex environmental and sustainability challenges (Wamsler et al., 2018). We currently live in a world of constrained resources, growing populations and exceed- ing planetary boundaries (Evans et al., 2017). During the past years, there has been a growing pressure to be more concerned with the environmental and resource consequences of the products, services and processes, and the relationship between the profit, people, and 
the planet (Kleindorfer et al., 2005; Ciarniene et al., 2018; Perkumiene et al., 2019). The three-pillar approach of sustainability covering an ecological, socio-cultural and economic pillars was agreed upon during the Johannesburg Summit in 2002 (Horlings, 2015). The challenge is to integrate the issues of sustainability with products, services, processes, work systems, and existing frameworks of employee behaviour both at home and at the workplace (Kleindorfer et al., 2005; Blake-Beard et al., 2010; Gimenez et al., 2012; Zink, 2014; De Medeiros et al., 2018; Pabian, 2019). Employees with different values and demographic profiles, e.g., generation, gender, education etc., have individual priorities, expectations, and perceive their environment differently (Horlings, 2015; Stirpe \& Zárraga-Oberty, 2017; Ciarniene et al., 2018). If so, they are likely to evaluate and respond to sustainable behaviour differently. A growing interest in sustainability and sustainable behaviour has been expressed in several research works that have examined various sustainability issues and contributed to the understanding of the outcomes for individuals, organisations and society. Although the scientific community has widely analysed the topic of sustainable behaviour during the past years, combinations of various employee-related factors affecting sustainable behaviour constitute a research gap to be further observed.

The purpose of this paper is to examine the influence of related factors on sustainable behaviour of working people. Therefore, the paper is organised as follows. The next section provides an analysis of the scientific literature on the dimensions of sustainability, the main characteristics of sustainable behaviour, and factors affecting the sustainable behaviour of employees. Section 3 presents research methods, and Section 4 examines how working people of Lithuania relate to sustainable behaviour across generations, genders and different modes of education. The final section of this paper provides a discussion, limitations and directions for future research works.

\section{LITERATURE REVIEW}

\subsection{THE DIMENSIONS OF SUSTAINABILITY}

Sustainable development is a major challenge facing people, organisations and societies today.
According to Kleindorfer et al. (2005), Gimenez et al. (2012), Martens \& Carvalho (2017), Ciarniene et al. (2018), and Spijkers (2018), sustainability integrates social, environmental, and economic responsibility to create a rational use of present resources, protect the welfare and well-being of every generation, and to offer a healthy and decent human environment for future generations. Environmental, social, and economic challenges have become increasingly complex, forcing people, organisations and societies to innovate, manage change, and adopt new technologies, new activities, new work arrangements, personal attitudes and behaviours (Horlings, 2015; Young et al., 2015; Martens \& Carvalho, 2017; Kim \& Park, 2017; Ciarniene et al., 2018; De Medeiros et al., 2018; Ahmed et al., 2019; Vveinhardt et al., 2019). Environmental sustainability is related to environmental integrity and protection, pollution control, the availability of natural resources and the protection of species and their ecosystems. Social sustainability makes sense of various concerns regarding the impact of products or operations on human rights, labour, health, safety, the well-being of organisational employees, regional development, and other community issues. The economic dimension refers to business sustainability and its human resources engaged in sustainable wealth creation processes, cost savings, operational efficiency, and financial performance (Katsoulakos \&, Katsoulacos, 2007; BlakeBeard et al., 2010; Horlings, 2015; Kim \& Park, 2017; Ciarniene et al., 2018).

Sustainability consists of a process of change through the dissemination of innovations, system innovations, sustainable innovations, transformations in existing production and consumption systems; consequently, it requires activities, mental models, and behaviours (Lozano, 2015; Evans et al., 2017; De Medeiros et al., 2018; Kułyk et al., 2017). The transformation to sustainability in the company, society and in the world is not only driven by practices and political structures, but also by beliefs, values, worldviews and paradigms that influence attitudes and actions (Horlings, 2015), and it begins with individual change. One cannot do for a community what one cannot do for one's self (Pappas \& Pappas, 2015). Insight in this "inner" dimension of sustainability helps us to understand the influence of ethical choices on daily activities and provides an insight into why people would accommodate change (Horlings, 2015). 


\subsection{MAIN CHARACTERISTICS OF SUSTAINABle BEHAVIOUR}

According to Pappas \& Pappas (2015), greater sustainability results from aligning our day-to-day behaviours with our well-stated values. Knowledge, values, and behaviours seem to be at the centre stage in the question of how to achieve transformations towards sustainability (Alroe et al., 2017). Sustainable behaviour has become an expression that is commonly used and is often substituted with other popular and trendy expressions, such as pro-ecological, environmentally friendly, eco-friendly, green behaviour, sustainable consumption behaviour, sustainable living, and sustainable cohabitation (Young et al., 2015; Sharma \& Jha, 2017; Huba, 2006; Minton et al., 2012; Poškus, 2016; Bulut et al., 2017; Kułyk et al., 2017; Diprose et al., 2019). Research on sustainable behaviour can be executed differently (Poškus, 2016). Some researchers focus on the cognitive and moral aspects of sustainable behaviour (Chan \& Bishop, 2013; Greaves et al., 2013). Other researches emphasise the role of personal values (Horlings, 2015; Jakovcevic \& Steg, 2013), while the third apply hands-on and experimental approaches (Bohner \& Schlüter, 2014) or place-based approaches (Messely, 2014; Horlings, 2015).

Describing sustainable behaviour Tapia-Fonllem et al. (2013) proposed to include pro-ecological, frugal, altruistic and equitable actions as instances of sustainable behaviour (Fig. 1). Pro-ecological behaviour is related to purposeful and effective actions that result in the conservation of natural resources. Recycling, composting, solid refuse control, water conservation, energy-saving behaviours, reading about environmental topics, and pro-ecological persuasion of others can be good examples of pro-ecological behaviours (Corral-Verdugo et al., 2010; Tapia-Fonllem et al., 2013). According to TapiaFonllem et al. (2013), frugality refers to a decreased level of consumption. It is an antagonist to consumerism and a fundamental behavioural characteristic of a sustainable lifestyle. Altruism can be defined as a motivational state aimed at increasing the wellbeing and benefits of others, the willingness to do things that bring advantages to others, with little or null interest in gains for oneself (Batson, 1991; Tapia-Fonllem et al., 2013). Equitable behaviour is related to sharing the satisfaction of needs between the present and future generations, the balance between human well-being and the integrity of ecosystems (Tapia-Fonllem et al., 2013).

Corral-Verdugo et al. (2010) produced a psychological measure of equitable behaviour, which included the assessment of social, racial, economic, age, and gender equity.

\subsection{FACTORS AFFECTING THE SUSTAINABLE BEHAVIOUR OF EMPLOYEES}

Horlings (2015) emphasised the value concept in understanding sustainable behaviour. Values are the essential foundation of society and the rules that define human interactions. Individual values can be changed by education, information communicated through the media, community or other social pressure, a scientific understanding, the example of a charismatic person, or a process of religious adoption or conversion. A combination of these change mechanisms is even more effective in modifying values (Dahl, 2019).

Research shows that priorities, expectations, and behaviours of employees are related to their values and demographic profiles, i.e., generation, gender,

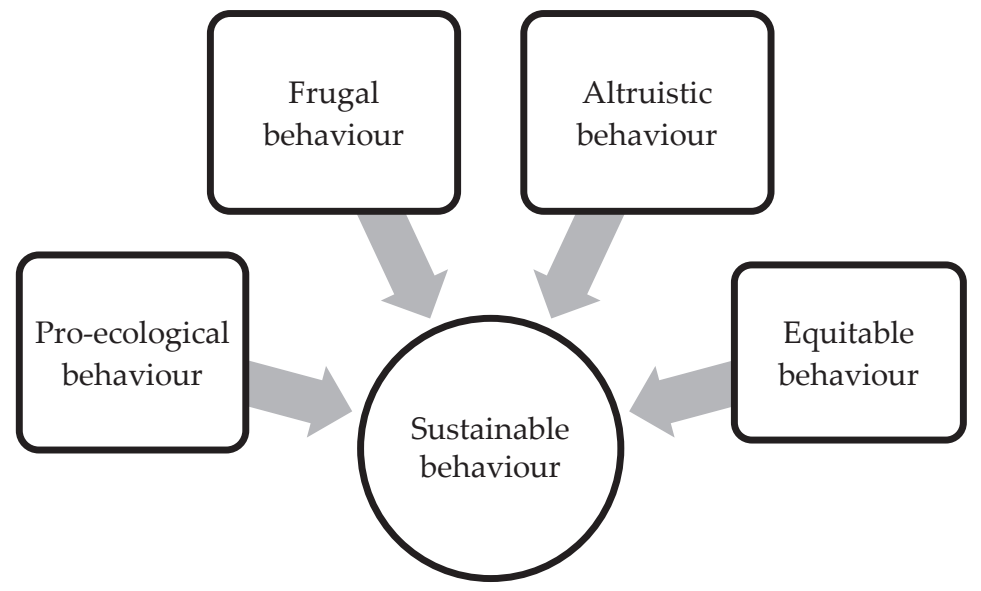

Fig. 1. Characteristics of sustainable behaviour

Source: elaborated by the authors based on (Tapia-Fonllem et al., 2013). 
and education (Stirpe \& Zárraga-Oberty, 2017; Ciarniene \& Vienazindiene, 2018). The concept of a generation refers to an aggregate of people differentiated from others by their year of birth, age, location, and significant life events at critical developmental stages (Sun \& Wang, 2010; Ciarniene \& Vienazindiene, 2018). Employees now fall into four main generations: the Traditional Generation (born 1922 to 1943); the Baby Boom Generation (born 1944 to 1964); the Generation X (born 1965 to 1981); and the Generation Y or Millennials (born 1982 to 2002) (Abrams \& Von Frank, 2014; Szydło, 2017).

Each generation is both a trustee of the planet with responsibilities to care for it and a beneficiary with rights to use it (Spijkers, 2018). But distinctive features of the generations likely provide some differences towards sustainability. Research of Diprose et al. (2019) disclosed a predominant generational narrative of frugality versus excess, with younger generations often negatively stereotyped as increasingly consumer-driven and environmentally destructive. Data showed that younger generations are more environmentally conscious and more likely to think about the environmental aspects of sustainable consumption. The research of Bulut et al. (2017) also showed that generation is associated with unneeded consumption as a dimension of sustainable consumption behaviour. According to this research, Baby Boomers were found to have the highest level of unneeded consumption behaviour while representatives of Generation Z - the lowest. According to Fleith De Medeiros et al. (2018), distinctive characteristics of generations cause some to have more sustainable actions (such as the Generation $\mathrm{Z}$ ), while others tend to have more self-directed behaviour and a short-term vision (such as the Generation X). According to Coughlin (2018), a majority of Millennials believe that they are more concerned about protecting the environment than older generations. Meanwhile, a majority of older people representing
Generation X and Baby Boomers saw themselves as more environmentally minded than when they were in their twenties. The older generations also performed a significant portion of volunteer work in the area of different environmental actions.

Gender role theory explains that men and women invoke different personal identities for their workfamily demands (Ciarniene \& Vienazindiene, 2018; Szydło, 2016). Although both men and women care about sustainability, their attitudes and practices towards sustainable behaviour can be different. The data of the study conducted by Khan and Trivedi (2015) confirmed that gender differences existed when it came to efficient use of resources, green initiatives, and minimising wastage. According to this research, women are more focused on purchasing and consuming products that are environmentally friendly, more thoughtful of energy conservation and other natural resources compared to men. Authors also highlighted that sustainable consumption needed to be differentiated into household and business needs-based consumption. Research findings by Bulut et al. (2017) supported the association between gender and sustainable consumption behaviour. According to this research, women showed a higher level of sustainable consumption behaviour and a higher tendency to reuse products.

Research results of Hamid et al. (2014) showed that sustainable consumer behaviour had a significant relationship with education. Different modes of education play a fundamental role in sustainable behaviour.

Based on the systematic and comparative literature analysis presented above, authors present a theoretical conceptual model, which illustrates the sustainable behaviour of employees (Fig. 2).

The key to living more sustainably is mainly about the choices that individuals, organisation, states and societies make. Sustainable employee behaviour (pro-ecological, frugal, altruistic and equi-

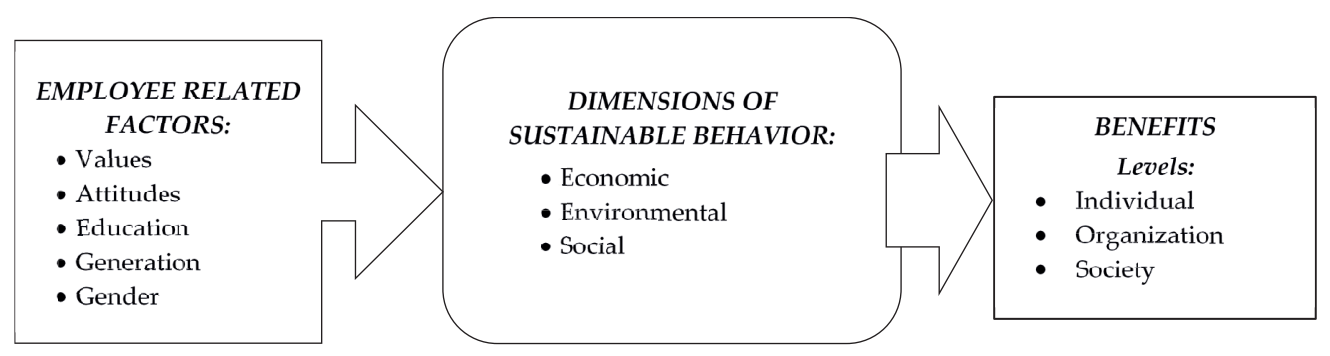

Fig. 2. Theoretical conceptual model of the sustainable behaviour of employees 
table actions) is influenced by employee-related factors and can be assessed through economic, environmental and social dimensions. Behaviour towards sustainability serves a triple purpose contributing to micro and macro levels, when meeting the needs of individuals, goals of an organisation and providing benefits to society as a whole.

\section{RESEARCH METHODS}

The empirical part focuses on employee-related factors and covers household activities of sustainable employee behaviour. This research aimed to examine how employees related to sustainable behaviour across generations, genders and different modes of education. To explore the research aim outlined above, a quantitative method was selected to capture individual employee attitudes and actions regarding sustainable behaviour.

The empirical research design consists of a survey developed by authors. The questionnaire was designed as a combination of two building blocks. The first block of questions was related to sociodemographic characteristics of respondents. The second block was devoted to disclosing of the manifestation of sustainable behaviour and the evaluation of these aspects in daily activities of employees:

- Economically sustainable behaviour domain consists of 13 statements (sources: Blake-Beard et al., 2010; Horlings, 2015; Ciarniene et al., 2018; De Medeiros et al., 2018; Kim \& Park, 2017; Katsoulakos \& Katsoulacos, 2007; Poškus, 2016; Bulut et al., 2017; Khan \& Trivedi, 2015), that evaluate sustainable wealth creation, minimising wastage, cost savings and other economic issues.

- Environmentally sustainable behaviour domain measures environmental integrity, protection of natural resources, recycling, composting, and energy-saving and consists of 17 statements (sources: Zink, 2014; Young et al., 2015; Sharma \& Jha, 2017; Huba, 2006; Minton et al., 2012; Hanson, 2013; Poškus, 2016; Bulut et al., 2017; Diprose et al., 2019; Messely, 2014; Tapia-Fonllem et al., 2013; Abrams \& Von Frank, 2014; Kułyk et al., 2017).

- Social sustainable behaviour domain consists of eight statements (sources: Blake-Beard et al., 2010; Ciarniene et al., 2018; De Medeiros et al., 2018; Spijkers, 2018; Kim \& Park, 2017; Poškus, 2016; Diprose et al., 2019; Coughlin, 2018), that evaluate pro-ecological learning and persuasion, human health and safety, reusing of products and other community concerns.

Some items are assigned to two or three domains. Each item is measured on a 5-point Likert scale ( $1=$ strongly disagree, $5=$ strongly agree). A higher score represents a more prevalent sustainable behaviour related to a particular aspect. Each domain score was calculated as a mean score for the scale.

After the initial pool of questionnaire items was created, the statements were reviewed by five qualified social science experts specialising in sustainable management and economics. The revision of the statements allowed making some corrections to be sure the statements were accurate, free of item construction problems, and grammatically correct. The reliability of the questionnaire was evaluated using its internal consistency of the questionnaire items estimating the Cronbach's alpha values. Cronbach's alpha values were as follows: the economically sustainable behaviour domain -0.80 ; the environmentally sustainable behaviour domain -0.85 ; and the socially sustainable behaviour domain -0.69 . Statistically significant strong correlations were found between every domain of sustainable behaviour. The strongest relationship was detected between economically and environmentally sustainable behaviour $(\mathrm{r}=0.980$, $\mathrm{p}<0.001)$. Pearson's correlation coefficients for economically and socially sustainable behaviour were $0.770(\mathrm{p}<0.001)$, and $\mathrm{r}=0.820(\mathrm{p}<0.001)$ for environmentally and socially sustainable behaviour.

A sample size calculator was used to determine the sample size (https://www.surveysystem.com/ sscalc.htm\#one). Based on the estimated sample, 430 questionnaires were delivered, using convenience sampling. Using this technique, data were obtained in the easiest possible manner. Data collection was conducted online and by distributing printed questionnaires to respondents. 412 questionnaires were filled out completely and were acceptable for analysis. The details of sample size are presented in Table 1.

The biggest part of respondents represented business sector employees (55.8\%) with more than 11 years of work experience (67.3\% of all the respondents). Sociodemographic characteristics of respondents are presented in Table 2.

The research was carried out in April - July 2019 in the Republic of Lithuania. All statistical analyses were conducted with SPSS version 22 (descriptive, two-way ANOVA and repeated measures ANOVA). 
Tab. 1. Population and sample size calculation

\begin{tabular}{|r|r|r|r|}
\hline \multicolumn{1}{|c|}{$\begin{array}{c}\text { Population SIZE } \\
\text { ThOUSAND }\end{array}$} & $\begin{array}{c}\text { CONFIDENCE LeVEL } \\
\%\end{array}$ & ConfIDENCE INTERVAL & SAMPLE SIZE \\
\hline $1388.9 *$ & 95 & 5 & 384 \\
\hline
\end{tabular}

*The number of employees (1st quarter of 2019)

Tab. 2. Sociodemographic characteristics of respondents

\begin{tabular}{|c|c|c|c|c|}
\hline \multirow[b]{2}{*}{$\begin{array}{l}\text { CHARACTERISTICS } \\
\text { (N (\%)) }\end{array}$} & \multicolumn{3}{|c|}{ GENERATION (THE YEAR RESPONDENTS WERE BORN) } & \multirow[b]{2}{*}{ TOTAL } \\
\hline & $\begin{array}{c}\text { ВАВY ВООМ } \\
1944-1964\end{array}$ & $\begin{array}{c}\text { GENERATION X } \\
1965-1981\end{array}$ & $\begin{array}{c}\text { GeNERATION } \\
\text { Y/ MILLENNIALS } \\
\text { 1982-2002 }\end{array}$ & \\
\hline Sample & $128(31.1 \%)$ & $124(30,1 \%)$ & $160(38.8 \%)$ & 412 \\
\hline Female & $80(62.5 \%)$ & $76(61.3 \%)$ & $76(47.5 \%)$ & $232(56.3 \%)$ \\
\hline Male & $48(37.5 \%)$ & $48(38.7 \%)$ & $84(52.5 \%)$ & $180(43.7 \%)$ \\
\hline
\end{tabular}

\section{RESEARCH RESULTS}

Data were collected from 412 employees (232 women and 180 men) representing three dominating generations across the labour market, i.e., the Baby Boomers, Generation X, and Generation Y. The largest part of respondents had a University education (332).

Respondents of the Baby Boomer Generation gained the highest scores on economically sustainable behaviour domain compared to younger participants of Generation X, and Generation Y $(\mathrm{F}(2.409)=4.175$, $\mathrm{p}=0.016$, Table 3 ). A higher level of sustainability related to economic issues was more typical to female respondents compared to male $(\mathrm{F}(1,409)=10.559$, $\mathrm{p}=0.001$, Table 3 ). The results revealed a significant effect of a generation and gender interaction on economically sustainable behaviour ( $\mathrm{F}(2.408)=4.350$, $\mathrm{p}=0.014)$. Sustainable behaviour related to the economic aspect was more prevalent for women of the Baby Boomer Generation (but not Generation X) compared to male respondents.

There was a significant main effect of education on economically sustainable behaviour. Surprisingly, sustainable behaviour related to economic issues was the most typical for subjects with the lowest education (i.e., secondary, $\mathrm{F}(2,409)=4.209$, $\mathrm{p}=0.016$; Table $3)$. Also, there was a significant education and a generation interaction effect (and the greatest one, considering partial etas2). This particular sustainable behaviour was least prevalent among the eldest respondents (Baby Boomers) with a college education and Generation $\mathrm{X}$ respondents with university education $(\mathrm{F}(4.395)=8.189, \mathrm{p}<0.001)$.
Scores of the environmentally sustainable behaviour domain were the highest for the Baby Boomer group of respondents $(\mathrm{F}(2,405)=7.432, \mathrm{p}=0.001$, Table 4). Female respondents had more prevalent sustainable behaviour and attitudes related to environmental issues compared to male $(\mathrm{F}(1,406)$ $=14.413, \mathrm{p}<0.001$, Table 4). There was a significant effect of the interaction between a generation and gender on environmentally sustainable behaviour and attitudes related to it $(\mathrm{F}(2.408)=14.413, \mathrm{p}<0.001)$. Sustainable behaviour related to environmental issues was the most prevalent among female respondents of the Baby Boomers and less prevalent among Generation Y compared to male respondents.

The score of the environmentally sustainable behaviour domain was the highest for the group of respondents with secondary education and the lowest for the ones with a college education (F $(2,407)=3.551, p=0.030$, Table 4). A statistically significant effect of the interaction between education and the year of birth was observed for environmentally sustainable behaviour and attitudes (F $(4,399)=8.128, \mathrm{p}<0.001$, Table 4). The highest scores for this domain were detected for the eldest respondents (the Baby Boomers) with a university and secondary education. Meanwhile, the most prevalent sustainable behaviour related to environmental issues was observed among Generation X respondents with secondary education.

Scores of the socially sustainable behaviour domain were the highest for the Baby Boomer respondents and the lowest for Generation $\mathrm{Y}$ respondents $(\mathrm{F}(2,408)=4.145, \mathrm{p}=0.017$, Table 5). The social aspect of sustainable behaviour was more important for female respondents compared to male 
Tab. 3. Effects of generation, gender and education on economically sustainable behaviour

\begin{tabular}{|c|c|c|c|c|c|c|c|}
\hline & \multirow{2}{*}{ CATEgory } & \multirow{2}{*}{ MEAN (ST.D.) } & \multicolumn{3}{|c|}{ GENERATION } & \multirow{2}{*}{ F, P } & \multirow{2}{*}{ PARTIAL ETA ${ }^{2}$} \\
\hline & & & BABY BOOM ${ }^{A}$ & GENERATION $\mathbf{X}^{\mathrm{B}}$ & GENERATION $Y^{c}$ & & \\
\hline \multirow{2}{*}{ Generation } & & & $3.84(0.58)$ & $3.67(0.56)$ & $3.68(0.51)$ & $\begin{array}{r}F=4,175, \\
p=0.016\end{array}$ & 0.020 \\
\hline & \multicolumn{2}{|c|}{ Post hoc comparisons } & \multirow{3}{*}{\multicolumn{3}{|c|}{$F=10,559, p=0.001$}} & $\begin{array}{l}p=0.033^{a-b} \\
p=0.041^{a-c} \\
p=0.968^{b-c}\end{array}$ & \\
\hline \multirow{2}{*}{ Gender } & \multirow{2}{*}{$\begin{array}{l}\text { Female } \\
\text { Male }\end{array}$} & $3.81(0.57)$ & & & & & \\
\hline & & $3.63(0.52)$ & & & & & \\
\hline \multirow{3}{*}{$\begin{array}{l}\text { Generation x } \\
\text { gender }\end{array}$} & Female & & $3.96(0.49)$ & $3.64(0.65)$ & $3.81(0.51)$ & \multirow{2}{*}{$\begin{array}{l}F=4,350 \\
p=0.014\end{array}$} & 0.021 \\
\hline & Male & & $3.65(0.66)$ & $3.71(0.38)$ & $3.58(0.49)$ & & \\
\hline & \multicolumn{2}{|c|}{ Post hoc comparisons } & $p=0.001$ & $p=0.454$ & $p=0.007$ & & \\
\hline \multirow{4}{*}{ Education } & $\begin{array}{l}\text { University } \\
\text { education }{ }^{d}\end{array}$ & $3.72(0.54)$ & & & & $\begin{array}{r}F=4,209, \\
p=0.016\end{array}$ & 0.021 \\
\hline & $\begin{array}{l}\text { College edu- } \\
\text { cation }^{e}\end{array}$ & $3.63(0.57)$ & & & & & \\
\hline & $\begin{array}{l}\text { Secondary } \\
\text { education }{ }^{f}\end{array}$ & $3.97(0.53)$ & & & & & \\
\hline & \multicolumn{2}{|c|}{ Post hoc comparisons } & & & & $\begin{array}{l}p=0.971^{d-e} \\
p=0.019^{d-f} \\
p=0.019^{e-f}\end{array}$ & \\
\hline \multirow{4}{*}{$\begin{array}{l}\text { Generation } \mathrm{x} \\
\text { education }\end{array}$} & $\begin{array}{l}\text { University } \\
\text { education }^{d}\end{array}$ & & $3.93(0.53)$ & $3.57(0.55)$ & $3.65(0.50)$ & $\begin{array}{l}F=8,189, \\
p<0.001\end{array}$ & 0.077 \\
\hline & $\begin{array}{l}\text { College edu- } \\
\text { cation }{ }^{\text {e }}\end{array}$ & & $3.23(0.43)$ & $3.89(0.54)$ & $3.77(0.49)$ & & \\
\hline & $\begin{array}{l}\text { Secondary } \\
\text { education }^{f}\end{array}$ & & $4.00(0.66)$ & $4.19(0.29)$ & $3.86(0.55)$ & & \\
\hline & \multicolumn{2}{|c|}{ Post hoc comparisons } & $\begin{array}{l}p<0.001^{d-e} \\
p=0.700^{d-f} \\
p=0.001^{\text {e-f }}\end{array}$ & $\begin{array}{l}p=0.013^{d-e} \\
p=0.001^{d-f} \\
p=0.171^{\text {e-f }}\end{array}$ & $\begin{array}{l}p=0.528^{\text {d-e }} \\
p=0.191^{d-f} \\
p=0.673^{\text {e-f }}\end{array}$ & & \\
\hline
\end{tabular}

$(\mathrm{F}(1,411)=49.480, \mathrm{p}<0.001$, Table 5$)$ and the analysis confirmed gender-related differences in this sustainable behaviour domain was significant enough (respondent's gender may explain about $10.8 \%$ of the change in socially sustainable behaviour and scores of the attitudes domain). The mean differences were statistically significant across every gender category, but it was the most statistically significant for the eldest respondents (the Baby Boomers). Statistically significant but minor differences were found in socially sustainable behaviour with respect to the level of education $(\mathrm{F}(2,409)=3.270, \mathrm{p}=0.039$, Table 5). The least prevalent sustainable behaviour (social aspect) was specific for respondents with a college education, and the most prevalent behaviour was specific for those with university and secondary education.

Results revealed a significant effect of the interaction between education and generation on socially sustainable behaviour and attitudes $(\mathrm{F}(4.403)=11.956$, $\mathrm{p}<0.001)$. Sustainable behaviour related to social issues was the most prevalent among the Baby Boomer respondents with university education and for Generation X respondents with secondary education.

Sustainable behaviour related to economic issues (the scale mean $3.69 \pm 0.60$ ) was a bit less prevalent compared to socially sustainable behaviour (the mean 3.74 $\pm 0.58 ; \mathrm{p}=0.047$ for pairwise comparison) and environmentally sustainable behaviour (mean $3.72 \pm 0.58, \mathrm{p}<0.001$ for pairwise comparison; $\mathrm{p}=0.728$ for pairwise comparison between scores of socially and environmentally sustainable behaviour domains) when evaluating the whole sample (repeated measures ANOVA's $\mathrm{F}(2.406)=11.411, \mathrm{p}<0.001$, partial eta2 0.053). 
Tab. 4. Effects of generation, gender and education on environmentally sustainable behaviour

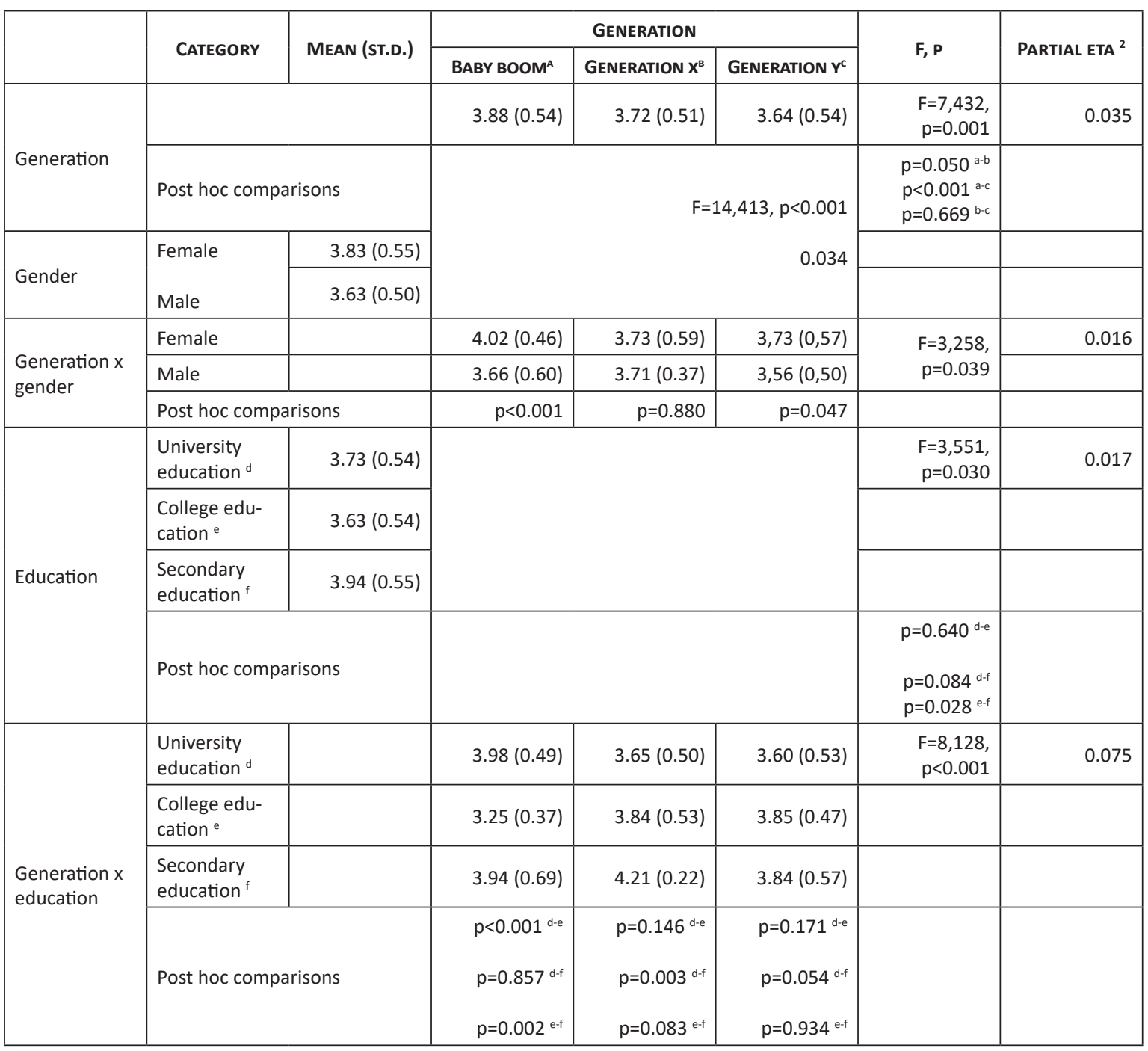

There was a statistically significant effect of a generation on evaluations of economically, environmentally and socially sustainable behaviour and attitudes (repeated measures ANOVA's $\mathrm{F}$ $(4,406)=5.747, \mathrm{p}=0.001$, partial eta2 0.027, Fig. 3). Economically sustainable behaviour was the least prevalent compared to environmental issues for the Baby Boomer respondents. Economically sustainable behaviour of Generation X respondents was rated as less prevalent compared to the sustainable behaviour related to social and environmental aspects. Generation Y respondents evaluated socially, environmentally and economically sustainable behaviour equally (pairwise comparisons $\mathrm{p}>0.05$ ).

Comparing various sustainable behaviour aspects and the importance of the particular sustainability area, differences were larger for the female sample compared to the male sample (female sample:
$\mathrm{F}(2.409)=26.525, \mathrm{p}<0.001$, partial eta2 0.115 ; male sample: $\mathrm{F}(2.409)=8.896, \mathrm{p}<0.001$, partial eta2 0.042). Females gained the highest scores on every sustainable behaviour domain compared to males (Fig. 4 and Tables 2 - 4). In the female sample, the most important and prevalent was socially sustainable behaviour (the mean score of the domain was 3.91; Fig. 4), and the least common was sustainable behaviour related to economic issues (the mean score of the domain was 3.74). The opposite results were for the male sample: they gained the lowest scores in the socially sustainable behaviour domain (the mean score was 3.53); meanwhile, the economically and environmentally sustainable behaviour and attitudes were more important for men (mean scores were 3.63 for both domains).

Participants with secondary school education $(\mathrm{F}(2.408)=1.107, \mathrm{p}=0.332$, partial eta2 0.005$)$ and 
Tab. 5. Effects of generation, gender and education on socially sustainable behaviour

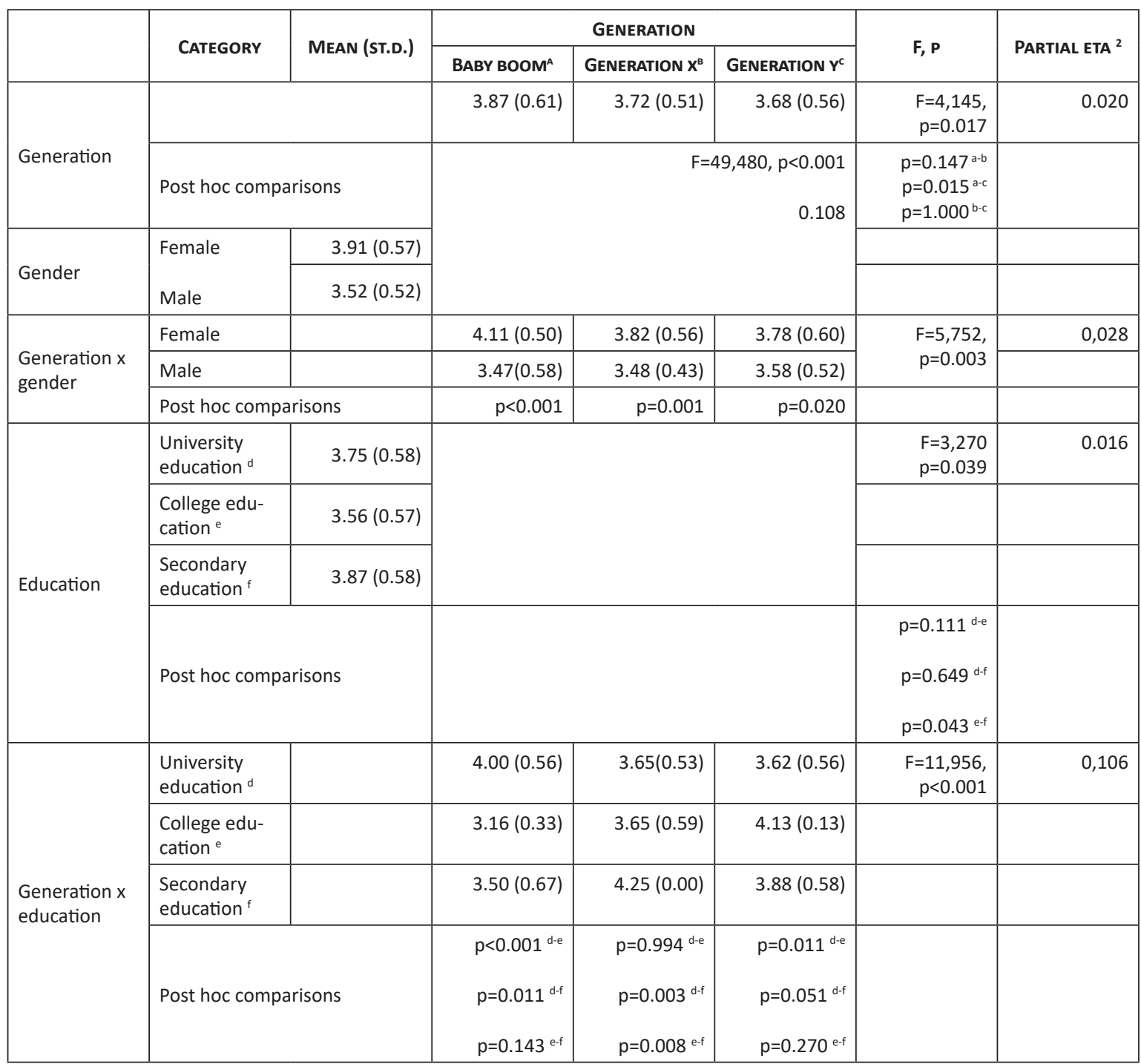

college education $(\mathrm{F}(2.408)=0.889, \mathrm{p}=0.412$, partial eta2 0.004; Fig. 5) valued economically, socially and environmentally sustainable behaviour and posture similarly (differences of mean scores of domains were statistically insignificant). Social aspects of sustainable behaviour were the most prevalent (the mean score of the domain was 3.75), and economic aspects of sustainability were the least important for the participants with university education (the mean score of the domain was 3.67; $\mathrm{F}(2.408)=14.102, \mathrm{p}<0.001$, partial eta2 0.065).

The analysis into the daily examples of sustainable behaviour by respondents in the whole sample determined that the highest percentage of assent was expressed in the following statements: I follow the opinion that it is not too late to learn and improve (95.10\%); I care about my health and those around me (94.20\%); I participate in deposit return schemes (92.20\%); I sort rubbish (plastic, glass...) (81.50\%); I don't smoke (80.60\%); I hand over suitable items (clothes, shoes, books, furniture ...) for secondary utilisation (77.70\%); I use electricity sparingly without leaving the electrical appliances unnecessarily (75.80\%); I use water sparingly (68.90\%); I use a reusable bag for shopping (65.10\%); My purchases are premeditated, I don't buy what I don't need (62.10\%); I don't throw away food (60.20\%).

The lowest percentage of assent was identified to the following statements: I travel to and from work by public transport, by bike or on foot (34\%); I use only environmentally friendly household products (cleaners, detergents ...) (34\%); I participate in environmental management campaigns and activities (39.80\%). 


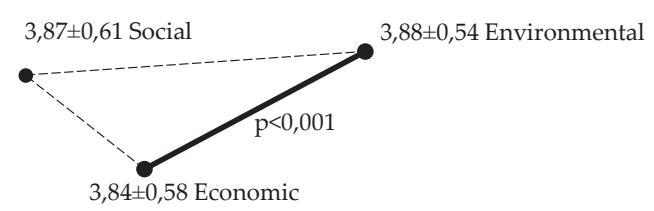

Statistically insignificant mean difference

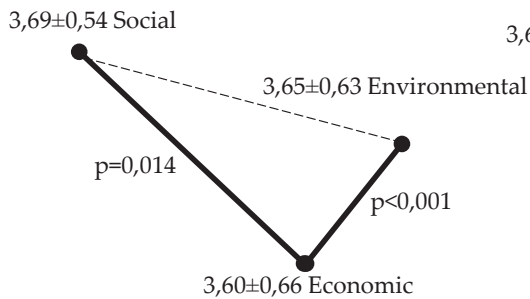

Baby Boom
$3,68 \pm 0,56$ Social

\section{-}

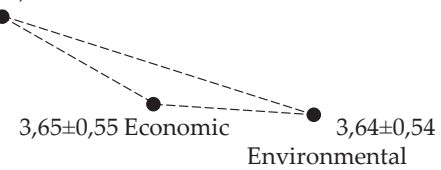

Environmental

Fig. 3. Sustainable behaviour from the perspective of a generation

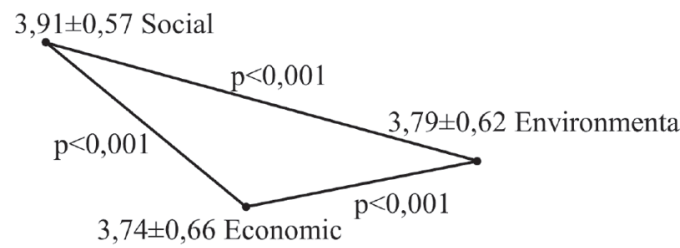

Statistically insignificant mean difference

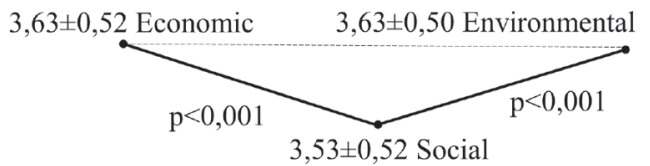

Female

Male

Fig. 4. Sustainable behaviour from the perspective of a gender

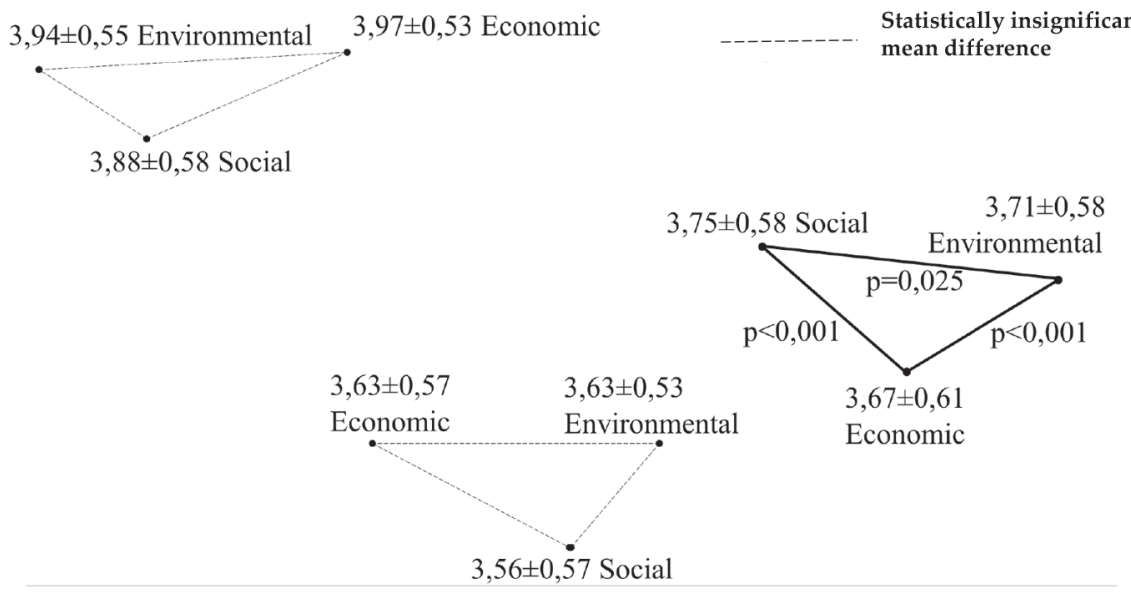

Secondary school education College education University education

Fig. 5. Sustainable behaviour from the perspective of education 


\section{DISCUSSION AND CONCLUSIONS}

The topic of sustainable development is widely analysed by the scientific community. A combination of various employee-related factors affecting sustainable behaviour constitutes a research gap to be observed. As a theoretical contribution, this study showed that sustainable employee behaviour was influenced by a collection of interrelated external (organisation, state and society) and internal (values, attitudes, education, generation and gender) factors. The empirical research of this article examined the manifestation of sustainable behaviour and the extent to which internal individual factors affected sustainable employee behaviour through economic, environmental and social domains.

It should be remarked that the results of the empirical research fit the theoretical background in this particular field. Khan and Trivedi (2015) and Bulut et al. (2017) argued that gender differences existed in green initiatives, minimising wastage, consumption behaviour and higher tendency to reuse products. The data of this study confirmed that gender differences existed when it came to sustainable behaviour. The results of empirical research were similar to the above-mentioned studies and also indicated that a higher level of sustainability related to economic, environmental and social issues was more typical for female respondents compared to male.

Research works by Diprose et al. (2019), Bulut et al. (2017), De Medeiros et al. (2018), Coughlin (2018) disclosed generational differences in sustainable consumption behaviour and actions. According to the results of these efforts, younger generations were more environmentally conscious and behaved more sustainably. This current research proved that there was a statistically significant generational effect on evaluations for economically, environmentally and socially sustainable behaviour and attitudes. But on the contrary to the above-mentioned results, in terms of generations, the Baby Boomer respondents gained the highest scores on all three sustainable behaviour domains compared to younger employees.

Hamid et al. (2014) identified that sustainable consumer behaviour had a significant relationship with education. This current research revealed that there was a significant effect of education on economically and environmentally sustainable behaviour and attitudes. Sustainable behaviour related to eco- nomic issues was most typical for respondents with the lowest education. Minor differences were identified in socially sustainable behaviour with respect to the level of education.

Sustainable behaviour related to economic issues was a little less prevalent compared to socially sustainable behaviour and environmentally sustainable behaviour when evaluating the whole sample. Summarising the analysis of daily examples of sustainable behaviour in the whole sample, the highest percentage of assent was determined in the following fields: continuous learning, care about health; participation in deposit return schemes; rubbish sorting; tendency to reuse products; and sparing use of different resources.

The limitation of this paper is that convenience sampling was used for this research and data gathering was not optimal. The sample size of some subgroups was not big enough to represent the entire population of working people; therefore, the authors express concerns about widely applicable generalisations. Another limitation of this research was that it explored only the sustainable behaviour of employees without an analysis of other population groups. It is the first stage of research on sustainable employee behaviour. It focused only on internal factors and covered only household activities of working people. Concerning further research, it would be worth exploring how employees behave in organisations and how organisations support and encourage their sustainable behaviour.

The current research study opened some space for scientific debate and future contributions. The findings on sustainable behaviour can be useful for organisation leaders, practitioners, and policy-makers, as they call for consistent contributions on micro and macro levels, meeting the needs of individuals, organisations and the whole society. It could be significant for international readers and scientists working in the area of sustainable behaviour when conducting comparative analyses of sustainable behaviour across different countries. It would allow revealing some similarities and specifics among different countries and cultures.

\section{LITERATURE}

Abrams, J., \& Von Frank, V. (2014). The Multigenerational Workplace-Communicate, Collaborate, and Create Community. Corwin Press. doi: 10.4135/9781483387741 
Ahmed, U., AlZgool, M., \& Shah, S. (2019). The impact of green human resource practices on environmental sustainability. Polish Journal of Management Studies, 20(1), 9-18.

Alrøe, H. F., Legun, M. S. K., Whitehead, J., Noe, E., Moller, H., \& Jon Manhire, J. (2017). Performance Versus Values in Sustainability Transformation of Food Systems. Sustainability, 9, 332. doi: 10.3390/su9030332

Batson, C. D. (1991). The Altruism Question: Toward a Social Psychological Answer. Hillsdale, United States: Erlbaum.

Blake-Beard, S., O’Neill, S. R., Ingols, C., \& Shapiro, M. (2010). Social Sustainability, Flexible Work Arrangements, and Diverse Women. Gender in Management: An International Journal, 25, 408-425.

Bohner, G., \& Schlüter, L. E. (2014). A Room With a Viewpoint Revisited: Descriptive Norms and Hotel Guests' towel Reuse Behavior. PLoS ONE, 9. doi: 10.1371/journal.pone.0104086

Bulut, Z. A., Çımrin, F. K., \& Dogan, O. (2017). Gender, generation and sustainable consumption: Exploring the Behaviour of Consumers from Izmir, Turkey. International Journal of Consumer Studies, 41, 597-604.

Chan, L., \& Bishop, B. A. (2013). Moral Basis for Recycling: Extending the Theory of Planned Behaviour. Journal of Environmental Psychology, 36, 96-102.

Ciarniene, R., \& Vienazindiene, M. (2018). Flexible Work Arrangements from Generation and Gender Perspectives: Evidence from Lithuania. Inžinerine ekonomika = Engineering Economics, 29, 84-92. doi: 10.5755/j01.ee.29.1.19247

Ciarniene, R., Vienazindiene, M., \& Adamoniene, R. (2018). Implementation of Flexible Work Arrangements for Sustainable Development. European Journal of Sustainable Development, 7, 11-21.

Corral-Verdugo, V., Frías-Armenta, M., \& García-Cadena, C. (2010). Introduction to the Psychological Dimensions of Sustainability. In: V. Corral-Verdugo, M. Frías-Armenta, \& C. García-Cadena (Eds.), Psychological Approaches to Sustainability (pp. 3-18). New York, United States: Nova Science Publishers.

Corral-Verdugo, V., Garcia-Cadena, C., Castro, L., Viramontes, I., \& Limones, R. (2010). Equity and Sustainable Lifestyles. In V. Corral-Verdugo, M. FriasArmenta, C. Garcia-Cadena (Eds.), Psychological Approaches to Sustainability (pp. 185-204). New York, United States:Nova Science Publishers.

Coughlin, J. (2018). Greener Than You: Boomers, Gen X \& Millennials Score Themselves On The Environment. Forbes. Retrieved from https://www.forbes. com/sites/josephcoughlin/2018/05/05/greenerthan-you-boomers-gen-x-millennials-score-themselves-on-the-environment/\#66277754d8b4

Dahl, L. A. (2019). Values as the Foundation for Sustainable Behaviour. International Environment Forum. Retrieved from https://iefworld.org/ddahl01b.htm

De Medeiros, J. F., Da Rocha, C. G., \& Ribeiro, J. L. D. (2018). Design for Sustainable Behavior (DfSB): Analysis of Existing Frameworks of Behavior Change Strategies, Experts' Assessment and Proposal for a Decision Support Diagram. Journal of Cleaner Production, 188, 402-415.
Diprose, K., Valentine, G., Vanderbeck, R. M., Liu, Ch., \& McQuaid, K. (2019). Building Common Cause Towards Sustainable Consumption: A Cross-generational Perspective. Environment and Planning E: Nature and Space, 2514-8486. doi: $10.1177 / 2514848619834845$

Evans, S., Lloyd, F., \& Yang, M. (2017). Sustainable Value Creation-From Concept Towards Implementation. In: R. Stark, G. Seliger, \& J. Bonvoisin (Eds.), Sustainable Manufacturing. Sustainable Production, Life Cycle Engineering and Management. Cham, Germany: Springer. doi: 10.1007/978-3-319-48514-0_13

Gimenez, C., Sierra, V., \& Rodon, J. (2012). Sustainable operations: their impact on the triple-bottom line. International Journal of Production Economics, 140, 149-159.

Greaves, M., Zibarras, L. D., \& Stride, C. (2013). Using the Theory of Planned Behavior to Explore Environmental Behavioral Intentions in the Workplace. Journal of Environmental Psychology, 34, 109-120.

Hamid, S. A. R, Khan, M. K. N., Kiani, S. T. M, Shah, T. Z., \& Kiani, S. (2014). The Impact of Education as Mediator on Sustainable Consumer Behavior. International Review of Management and Business Research, 3, 1905-1913.

Hanson, M. A. (2013). Green Ergonomics: Challenges and Opportunities. Ergonomics, 56, 399-408.

Horlings, L. G. (2015). Values in Place; A Value-oriented Approach Toward Sustainable Place-shaping. Regional Studies, Regional Science, 2, 257-274. doi: 10.1080/21681376.2015.1014062

Huba, M. (2006). Values for a Sustainable Future vs. Global Problems and Threats. Filozofia, 61, 520-532.

Jakovcevic, A., \& Steg, L. (2013). Sustainable transportation in Argentina: Values, Beliefs, Norms and Car Use Reduction. Transportation Research Part F: Traffic Psychology and Behaviour, 20, 70-79.

Katsoulakos, T., \& Katsoulacos, Y. (2007). Integrating Corporate Responsibility Principles and Stakeholder Approaches into Mainstream Strategy: A Stakeholder-oriented and Integrative Strategic Management Framework. Corporate Governance, 7, 355-369. doi: $10.1108 / 14720700710820443$

Khan, N., \& Trivedi, P. (2015). Gender Differences and Sustainable Consumption Behavior. British Journal of Marketing Studies, 3, 29-35.

Kim, W., \& Park, J. (2017). Examining Structural Relationships between Work Engagement, Organizational Procedural Justice, Knowledge Sharing, and Innovative Work Behavior for Sustainable Organizations. Sustainability, 9, 205. doi: 10.3390/su9020205

Kleindorfer, P. R., Singhal, K., \& Van Wassenhove, L. (2005). Sustainable Operations Management. Production and Operations Management, 14, 482-492.

Kułyk, P., Michałowska, M., \& Patelska, M. (2017). Consumer attitudes in the light of the concept of sustainable consumption in Lubuskie voivodeship against the background of trends in consumption in Poland. Oeconomia Copernicana, 8(2), 181-198.

Lozano, R. (2015). A holistic Perspective on Corporate Sustainability Drivers. Corporate Social Responsibility and Environmental Management, 22, 32-44. 
Martens, M. L., \& Carvalho, M. M. (2017). Key Factors of Sustainability in Project Management Context: A Survey Exploring the Project Managers' Perspective. International Journal of Project Management, 35, 1084-1102.

Messely, L. (2014). On Regions and Their Actors: An Analysis of the Role of Actors and Policy in Region Specific Rural Development Processes in Flanders. (PhD-thesis). Ghent, Belgium: Ghent University.

Minton, E., Lee, C., Orth, U., Kim, C., \& Kahle, L. (2012). Sustainable Marketing and Social Media: A Crosscountry Analysis of Motives for Sustainable Behaviors. Journal of Advertising, 41, 69-84.

Pabian, A. M. (2019). University social responsibility in the opinion of students. Forum Scientiae Oeconomia, 7 , 101-117.

Pappas, J. B., \& Pappas, E. C. (2015). The Sustainable Personality: Values and Behaviors in Individual Sustainability. International Journal of Higher Education, 4, $12-21$.

Perkumienè, D., Vienažindienė, M., \& Švagždienė, B. (2019). Cooperation Perspectives in Sustainable Medical Tourism: The Case of Lithuania. Sustainability, 11, 3584. doi: 10.3390/su11133584

Poškus, M. S. (2016). Using Social Norms to Encourage Sustainable Behaviour: a Meta-analysis. Psichologija, $53,44-58$

Sharma, R., \& Jha, M. (2017). Values Influencing Sustainable Consumption Behaviour: Exploring the Contextual Relationship. Journal of Business Research, 76, 77-88.

Spijkers, O. (2018). Intergenerational Equity and the Sustainable Development Goals. Sustainability, 10, 3836.

Stirpe, L., \& Zárraga-Oberty, C. (2017). Are High-Performance Work Systems Always a Valuable Retention Tool? The Roles of Workforce Feminization and Flexible Work Arrangements. European Management Journal, 35, 128-136.

Sun, J., \& Wang, X. (2010). Value Differences Between Generations in China: a Study in Shanghai. Journal of Youth Studies, 13, 65-81.

Szydło, J. (2017). Differences between Values Preferred by Generations X, Y and Z. Przedsiębiorczość i Zarządzanie, 18(3-1), 89-100.

Szydło, J. (2016). Masculinity vs Femininity in Polish and Ukrainian Organisational Cultures. Journal of Intercultural Management, 8(4), 117-132.

Tapia-Fonllem, C., Corral-Verdugo, V., Fraijo-Sing, B., \& Durón-Ramos, M. F. (2013). Assessing Sustainable Behavior and its Correlates: A Measure of ProEcological, Frugal, Altruistic and Equitable Actions. Sustainability, 5, 711-723.

Vveinhardt, J., Fominiene, V. B., Andriukaitiene, R. (2019). "Omerta" in Organized Sport: Bullying and Harassment as Determinants of Threats of Social Sustainability at the Individual Level. Sustainability, 11, 2474 .

Wamsler, C., Brossmann, J., Hendersson, H., Kristjansdottir, R., McDonald, C., \& Scarampi, P. (2018). Mindfulness in Sustainability Science, Practice, and Teaching. Sustainability Science, 13, 143-162.
Young, W., Davis, M., McNeill, I. M., Malhotra, B., Russell, S., Unsworth, K., \& Clegg, C. W. (2015). Changing Behaviour: Successful Environmental Programmes in the Workplace. Business Strategy and the Environment, 8, 689-703.

Zink, K. J. (2014). Designing Sustainable Work Systems: the Need for a Systems Approach. Applied Ergonomics, $45,126-132$. 